\title{
Solar Energy Measurement Using Arduino
}

\author{
Siti Amely Jumaat ${ }^{1}$, Mohamad Hilmi Othman $^{1}$ \\ ${ }^{1}$ Green and Sustainable Energy Focus Group, Faculty of Electrical and Electronic Engineering, Universiti Tun Hussein Onn Malaysia. \\ 86400 Parit Raja, Batu Pahat, Johor, Malaysia.
}

\begin{abstract}
This project aims to develop a measurement of solar energy using Arduino Board technology. In this research, four parameters that been measured are temperature, light intensity, voltage and current. The temperature was measured using temperature sensor. The light intensity was measured using light dependent resistor (LDR) sensor. The voltage was measured using the voltage divider because the voltage generated by the solar panel are large for the Arduino as receiver. Lastly for the current was measured using the current sensor module that can sense the current generated by the solar panel. These parameters as the input value for the Arduino and the output was display at the Liquid Crystal Display (LCD) screen. The LCD screen display output of the temperature, the light intensity, the voltage and the current value. The purpose of Arduino to convert the analog input of parameter to the digital output and display via LCD screen. Other than that, this project also involve with a design to ensure that device case are easy to be carry around.
\end{abstract}

\section{Introduction}

Rising fossil fuel and burning fuel such as coal, global warming and severe weather conditions have compelled many nations to look for alternative sources to reduce reliance on fossil based fuels. Solar energy is one of the most promising renewable sources that is currently being used worldwide to contribute for meeting rising demands of electric power. [1] Solar power is a conversion of sunlight into electricity, sunlight was collect either directly by using photovoltaics or indirectly using concentrated of solar energy. [2]

Photovoltaics was initially use as a power source for a small and medium-size applications from the calculator powered by a single solar cell to a remote homes powered by an off-grid rooftop photovoltaics system. As the cost of solar electricity has fallen, the number of grid-connected solar photovoltaics systems has grown into the millions and utility scale solar power stations with hundreds of megawatts are being built. Solar photovoltaic is becoming inexpensive, low-carbon technology to harness renewable energy from the sun. [3] This paper presented by Arindam Bose et. al [4] describe a potential a solar system using two set of stepper motor, the light sensor and the concave mirror. The purpose of this project to improve the power collection efficiency $65 \%$ with developing the track of solar panel perpendicular. This paper presented by Mohsen Taherbaneh et. al [5] proposed the method based on simulation of two fuzzy controllers in order to maximize the generate the output power of solar panel in a photovoltaic system. The output $\mathrm{I}-\mathrm{V}$ curve from this project are the maximum current is $1.56 \mathrm{~A}$ nad the maximum voltage are $20 \mathrm{~V}$ with solar irradiance $=$ $500 \mathrm{~W} / \mathrm{m}^{2}$ and temperature $=34.5^{\circ} \mathrm{C}$. The results of the fuzzy-based maximum power point tracking with $23 \mathrm{~W}$ with $51 \%$ and $11 \mathrm{~W}$ with $24.5 \%$ from the nominal output power. On the other hand, the combination of fuzzy-based maximum power point tracking and fuzzybased sun tracking is $35 \mathrm{~W}$ with $78 \%$ of the nominal output power. Yi-Hua Liu et.al in [6] presented the maximum power point tracking (MPPT) method for low power photovoltaic system, $87 \mathrm{~W}$ PV system. The MPPT circuit using the low power operational amplifier (OPAMP) with high and low irradation line and an analog switch. The simple DC-DC converter using such as the interface the voltage from the PV system. The type of multi-crystalline solar cell KC85T with the nominal open-circuit voltage of $21.7 \mathrm{~V}$ and the nominal voltage at the maximum power point of $17.4 \mathrm{~V}$. The simulation results shows with $1000 \mathrm{~W} / \mathrm{m}^{2}$ irradiance, $25^{\circ} \mathrm{C}$ and the maximum power is $87.46 \mathrm{~W}$. From experimental results with $1000 \mathrm{~W} / \mathrm{m}^{2}$, the maximum power is $87.39 \mathrm{~W}$. The advantages of analog MPPT are very simple, the lowpower analog component, the fast speed and can using to all types of power convertes. This paper [7] propose the method the Fibonnaci search technique for narrow down possible locations. The results shows that $1000 \mathrm{~W} / \mathrm{m}^{2}$ is $112.4 \mathrm{~W}$ with $13 \%$ efficiency of panel solar. Mohammad H. Moradi presented in [8] to improve the performance of the maximum power point tracking in solar panel. The PV panel with Aria Solar are $60 \mathrm{~W}$, with $25^{\circ} \mathrm{C}, 1000 \mathrm{~W} / \mathrm{m}^{2}$

\footnotetext{
* Corresponding author: sitiamely1979@gmail.com
} 
and the current is $2.5 \mathrm{~A}$ and the voltage is $23.1 \mathrm{~V}$. The proposed algorithm are the set point calculation and the fine turning loops. The method was simulated with Matlab/Simulink and also development of the prototype.

Concentration of solar energy are concentration of the light from the sun to a point by using lens or mirror and tracking system. The light from the sun also produce heat and if we concentrate at a point. The point will experience the heat produce from the sun [9-10].

This project are focus on measure the solar power using Arduino [10]. This design project are to measured parameters: light intensity, voltage and current and temperature using multiple sensor. The main part in this project are the solar panel, the light sensor, the temperature sensor, a voltage divider, the current sensor and the LCD screen to display.

\section{Specification of Components}

This part are discusses the main components that used on this research.

\subsection{Solar Cell}

In this research, the panel solar is polycrystalline type are be used with $12 \mathrm{~V}, 250 \mathrm{~mA}, 3 \mathrm{~W}$ as a source [9]. The size of the panel is $145 \mathrm{~mm} \mathrm{X} 145 \mathrm{~mm}$ as shown in Figure 1.

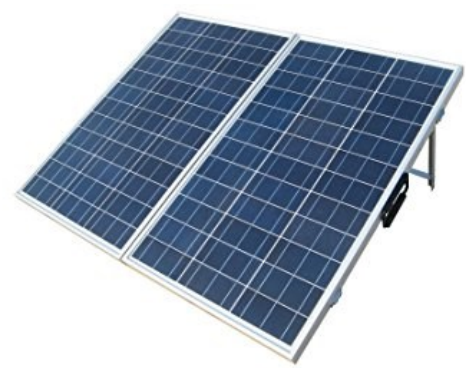

Fig. 1. The Solar Panel Polycrystalline Type

\subsection{Arduino Board}

The Arduino Uno is microcontroller board based on the ATmega328 datasheet as shown in Figure 2. It has 14 digital input and output pins: 6 pins used PWM outputs and 6 pins is analog input such as the clock speed is $16 \mathrm{MHz}$, the ceramic resonator, the USB connection, the power jack, the ICSP header and the reset button [10].

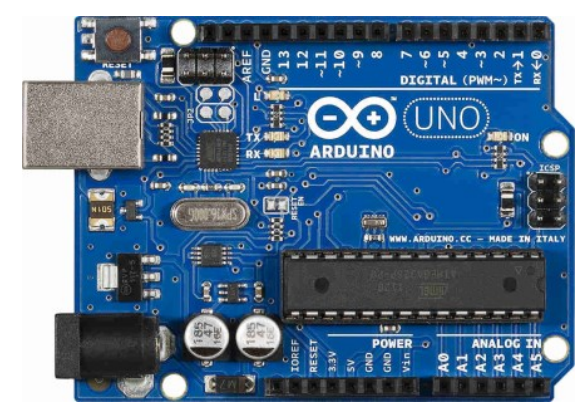

Fig. 2. The Arduino Board

\subsection{Light Sensor}

A Light Dependent Resistor (LDR) or photo resistor is device whose resistivity is a function of the incident electromagnetic radiation which means it is light sensitive devices. These components also called a photo conductors, photo conductive cells or simply photocells [11]. The LDR function on the principle based on photo conductivity which an optical phenomena. Figure 3 shows the resistance vs illumination graph of LDR.

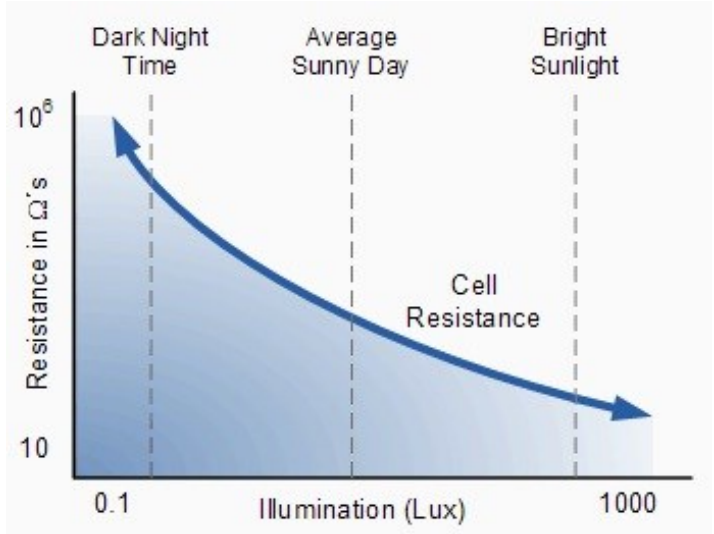

Fig. 3. The resistance VS illumination Graph of LDR

\subsection{Circuit Simulation}

Figure 4(a) and (b) shown the block diagram of the research and the complete of simulation circuit for this project that have been develop by using Proteus 8 Professiona [12-16]. In this simulation circuit, it consist three main parts: the voltage divider, the LED light indicator, the temperature sensor, LDR sensor and the LCD screen display. The power generated from the solar panel is $12 \mathrm{~V}$ approximately. Inside the circuit have LDR sensor for detect the light intensity. Next, the temperature sensor have detect the temperature changing $[17-18,20]$. In this project, the main controller are use the Arduino Uno and its need the power supply [16, 19, 21]. The power supply for this controller is $5 \mathrm{~V}$. Then, the Arduino Uno must have coding for it to function as desired. Lastly, the LCD is to display the output that have written in the coding inside the Arduino Uno [2223].

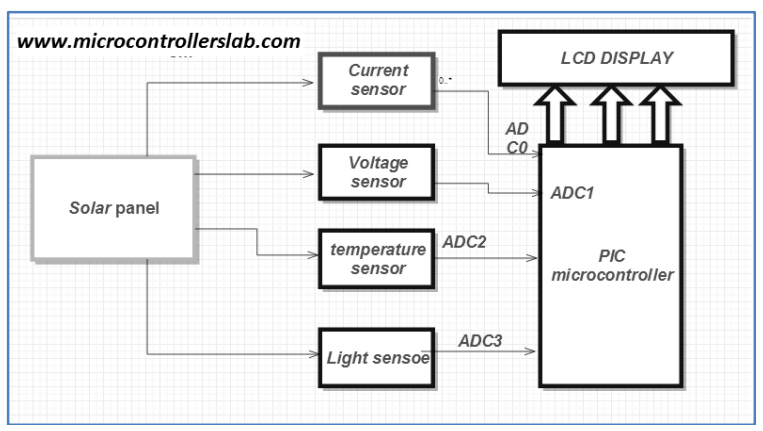

Fig. 4(a). The block diagram of the research 


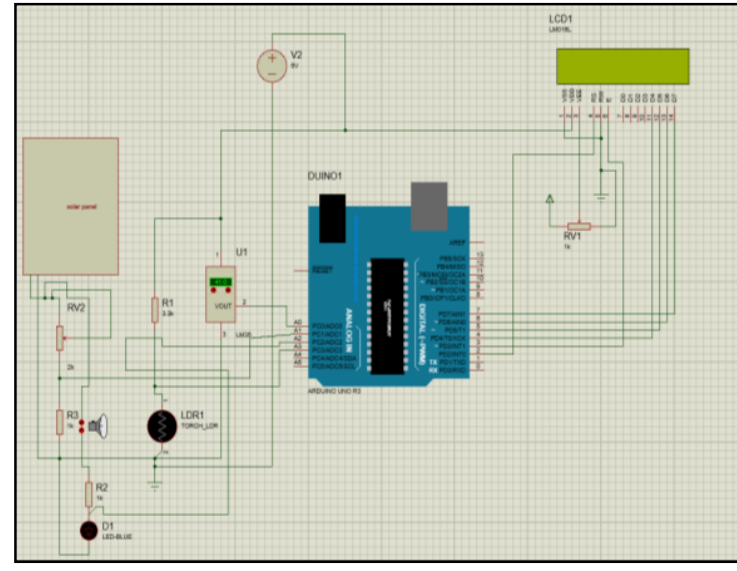

Fig. 4(b). The Simulation Circuit

\section{Result and Analysis}

This section are discusses the results based on the simulation results and the measurement result.

\subsection{Simulation Results}

Figure 5 shown the results of the temperature. It varies depend on the temperature sensor setting during the simulation. The Table 1 shown the simulation result of light intensity and the output voltage. From the simulation results shown that the circuit are function is very well and can be continue to the hardware development.

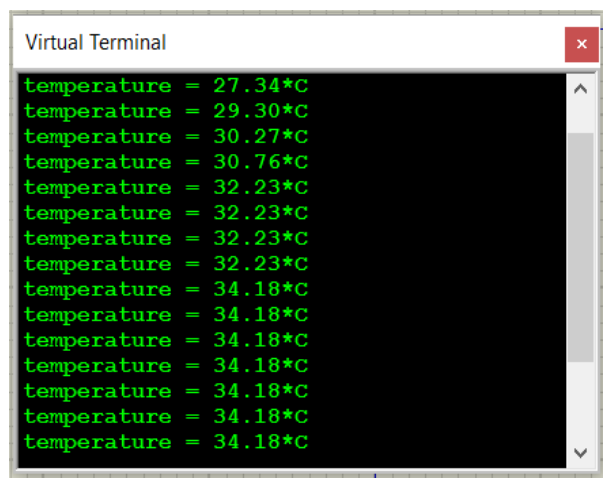

Fig. 5. The temperature virtual terminal output

Table 1. LDR simulation result

\begin{tabular}{|c|c|c|}
\hline LDR (Lux) & LDR intensity & Output Voltage (V) \\
\hline 0.1 & 11 & 0.0538 \\
\hline 10.1 & 372 & 1.8174 \\
\hline 20.1 & 520 & 2.5379 \\
\hline 30.1 & 607 & 2.9655 \\
\hline 40.1 & 667 & 3.2545 \\
\hline
\end{tabular}

\subsection{Measurement Results}

These sections are divided to three main parts: the light intensity, the voltage versus light intensity and the output power.

\subsubsection{Results of Light Intensity}

The light intensity have been recorded in the three days with the solar panel in the sunrise position as shown in Figure 6 . Based on the result, the highest light intensity was 980 Lux at $2.00 \mathrm{pm}$, while the lowest light intensity was 700 Lux at $5.00 \mathrm{pm}$. The light intensity have been recorded in the three days with the solar panel in the sunrise position as shown in Figure 7. Based on the result, the highest light intensity was 970 Lux at $11.00 \mathrm{am}$, while the lowest light intensity was $350 \mathrm{Lux}$ at $5.00 \mathrm{pm}$. The light intensity have been recorded in the three days with the solar panel in the sunrise position as shown in Figure 7. Based on the result, the highest light intensity was 970 Lux at $11.00 \mathrm{am}$, while the lowest light intensity was $350 \mathrm{Lux}$ at $5.00 \mathrm{pm}$. The light intensity have been recorded in the three days with the solar panel in the sunrise position as shown in Figure 8. Based on the result, the highest light intensity was 950 Lux at $12.00 \mathrm{pm}$, while the lowest light intensity was $830 \mathrm{Lux}$ at $5.00 \mathrm{pm}$.

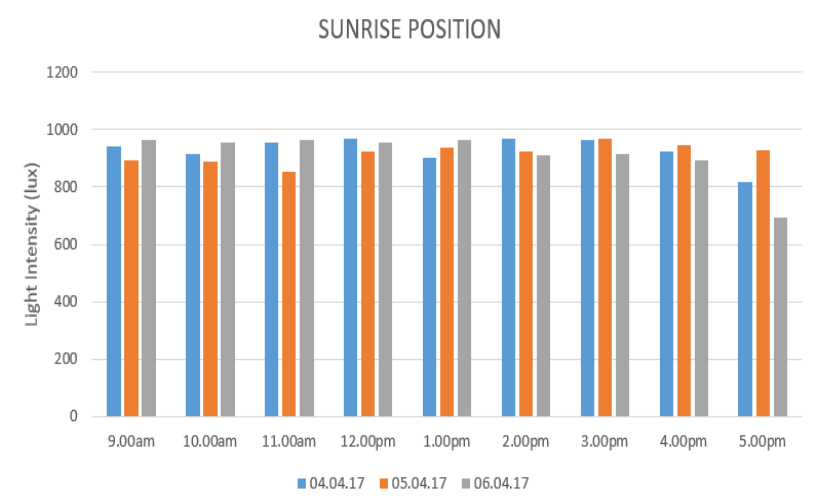

Fig. 6. Result of light intensity for sunrise position

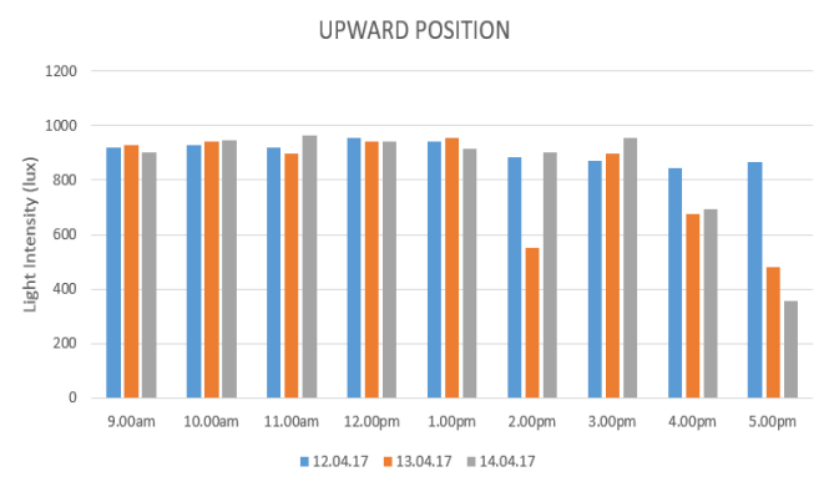

Fig. 7. Result for light intensity for upward position 


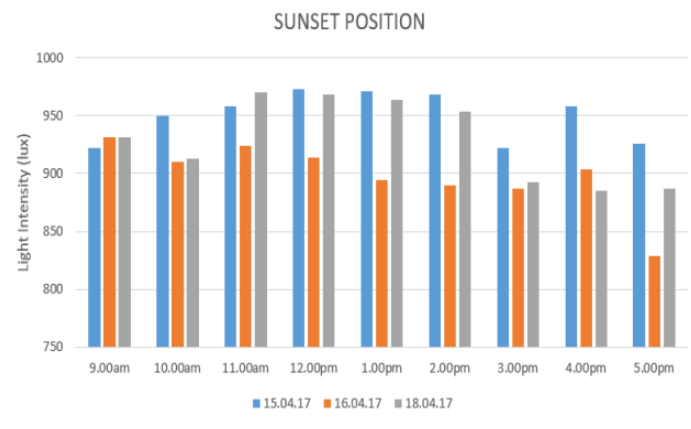

Fig. 8. Result for light intensity for sunset position

Table 2 shown the maximum and the minimum of the light intensity that have been recorded according to their solar panel position.

Table 2: Maximum and minimum light intensity.

\begin{tabular}{|c|c|c|c|}
\hline Position & Sunrise & Upward & Sunset \\
\hline $\begin{array}{c}\text { Maximum } \\
\text { (Lux) }\end{array}$ & $\begin{array}{c}980 \mathrm{Lux} \text { at } \\
2.00 \mathrm{pm}\end{array}$ & $\begin{array}{c}\text { 970 Lux at } \\
11.00 \mathrm{am}\end{array}$ & $\begin{array}{c}950 \mathrm{Lux} \text { at } \\
12.00 \mathrm{pm}\end{array}$ \\
\hline $\begin{array}{c}\text { Minimum } \\
\text { (Lux) }\end{array}$ & $\begin{array}{c}700 \mathrm{Lux} \text { at } \\
5.00 \mathrm{pm}\end{array}$ & $\begin{array}{c}350 \mathrm{Lux} \text { at } \\
5.00 \mathrm{pm}\end{array}$ & $\begin{array}{c}830 \mathrm{Lux} \text { at } \\
5.00 \mathrm{pm}\end{array}$ \\
\hline
\end{tabular}

\subsubsection{Results of Voltage versus Light Intensity}

The result voltage versus light intensity for the solar panel in sunrise position as shown in Figure 9. The highest voltage recorded was $14.75 \mathrm{~V}$ at $11.00 \mathrm{am}$ with light intensity was $945 \mathrm{Lux}$ and the lowest voltage recorded was $9.17 \mathrm{~V}$ at $5.00 \mathrm{pm}$ with light intensity was 695 Lux. The result voltage versus light intensity for the solar panel in upward position as shown in Figure 10. The highest voltage recorded was $13.11 \mathrm{~V}$ at $10.00 \mathrm{am}$ with light intensity was 929 Lux and the lowest voltage recorded was $6.3 \mathrm{~V}$ at $5.00 \mathrm{pm}$ with light intensity was 357 Lux. The result voltage versus light intensity for the solar panel in sunset position as shown in Figure 11. The highest voltage recorded was $12.57 \mathrm{~V}$ at $1.00 \mathrm{pm}$ with light intensity was 964 Lux and the lowest voltage recorded was $11.19 \mathrm{~V}$ at $9.00 \mathrm{am}$ with light intensity was 931 Lux.

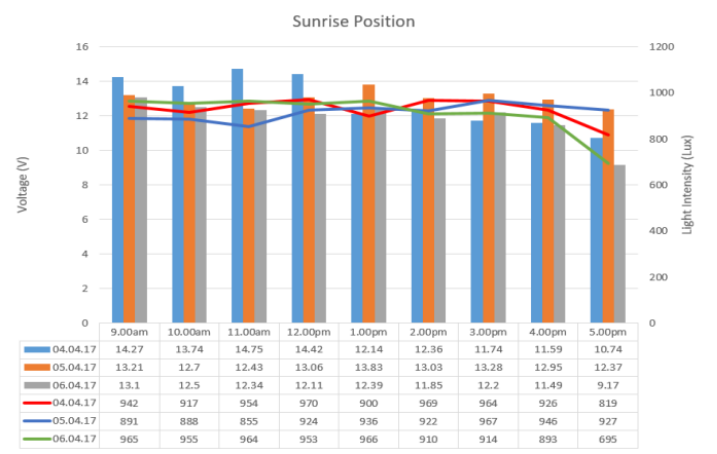

Fig. 9. Voltage versus light intensity for sunrise position.

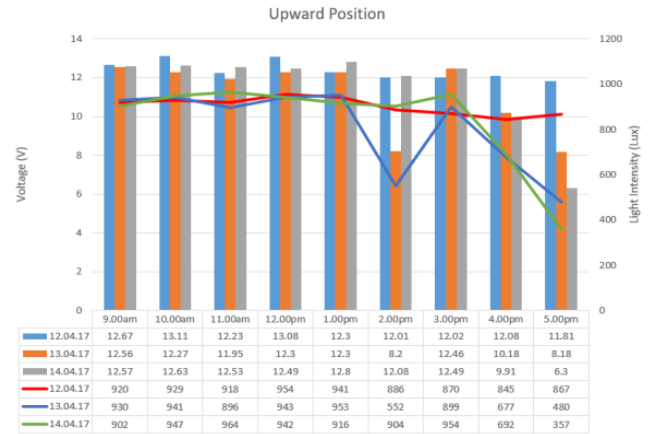

Fig. 10. Voltage versus light intensity for upward position.

Table 3 shown the maximum and minimum value of voltage and light intensity for each of the position. From the shows that, the higher voltage value, the light intensity also have higher value. The present of light intensity will affect the voltage produce by the solar panel.

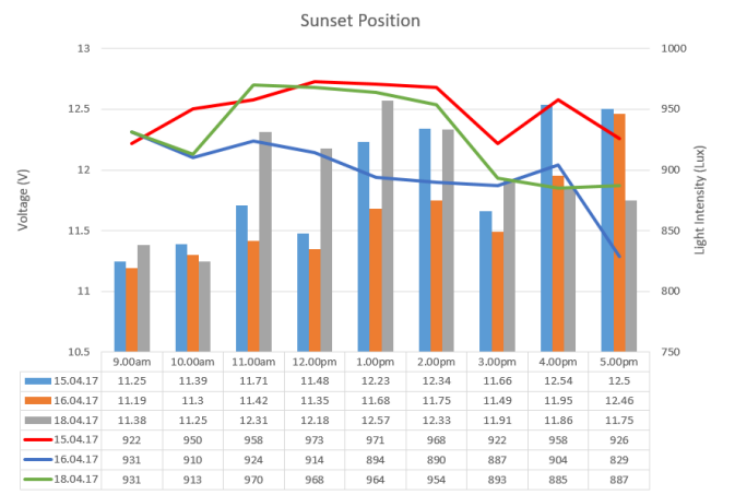

Fig. 11. Voltage versus light intensity for sunset position.

Table 3. The maximum and minimum value for each position.

\begin{tabular}{|c|c|c|c|}
\hline Position & Sunrise & Upward & Sunset \\
\hline Maximum & $\begin{array}{c}14.75 \mathrm{~V} \\
(11.00 \mathrm{am}) \\
\text { with 954 } \\
\text { Lux }\end{array}$ & $\begin{array}{c}13.11 \mathrm{~V} \\
(10.00 \mathrm{am}) \\
\text { with 929 } \\
\text { Lux }\end{array}$ & $\begin{array}{c}12.57 \mathrm{~V} \\
(1.00 \mathrm{pm}) \\
\text { with 964 } \\
\text { Lux }\end{array}$ \\
\hline Minimum & $\begin{array}{c}9.17 \mathrm{~V} \\
(5.00 \mathrm{pm}) \\
\text { with 695 } \\
\text { Lux }\end{array}$ & $\begin{array}{c}6.3 \mathrm{~V} \\
(5.00 \mathrm{pm}) \\
\text { with 357 } \\
\text { Lux }\end{array}$ & $\begin{array}{c}11.19 \mathrm{~V} \\
(5.00 \mathrm{pm}) \\
\text { with 931 } \\
\text { Lux }\end{array}$ \\
\hline
\end{tabular}

\subsubsection{Results of Output Power}

The result of output power with the solar panel in the sunrise position was shown in Figure 12. The highest power produce was $2.4 \mathrm{~W}$ at $4.00 \mathrm{pm}$, while the lowest power produce $0.3 \mathrm{~W}$ at $5.00 \mathrm{pm}$. The result of output power with the solar panel in the upward position was shown in Figure 13. The highest power produce was $1.7 \mathrm{~W}$ at $12.00 \mathrm{pm}$, while the lowest power produce $0.38 \mathrm{~W}$ at $5.00 \mathrm{pm}$. The result of output power with the solar panel in the sunset position was shown in Figure 
14. The highest power produce was $1.63 \mathrm{~W}$ at $5.00 \mathrm{pm}$, while the lowest power produce $1.21 \mathrm{~W}$ at $9.00 \mathrm{am}$.

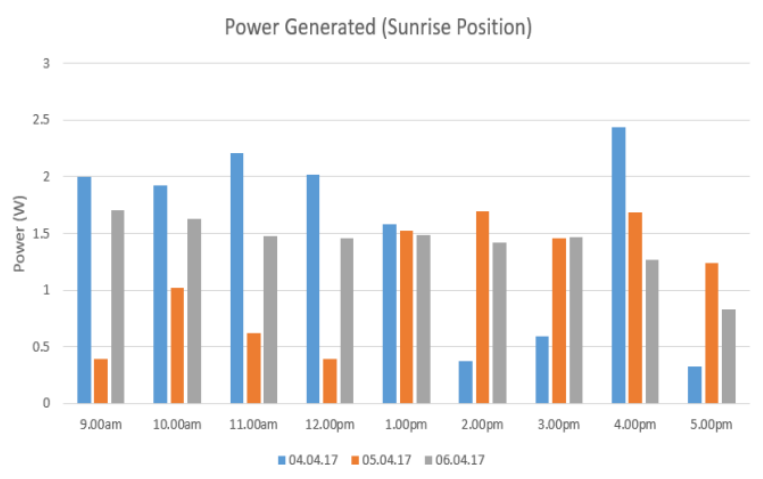

Fig. 12. Power from the sunrise position.

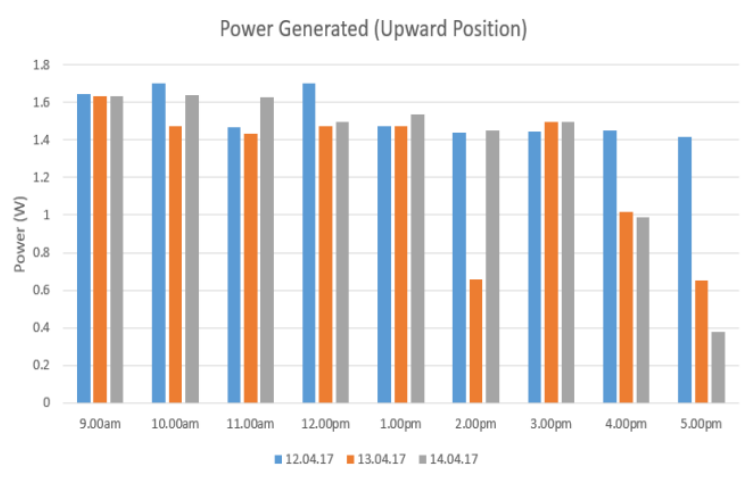

Fig. 13. Power from the upward position.

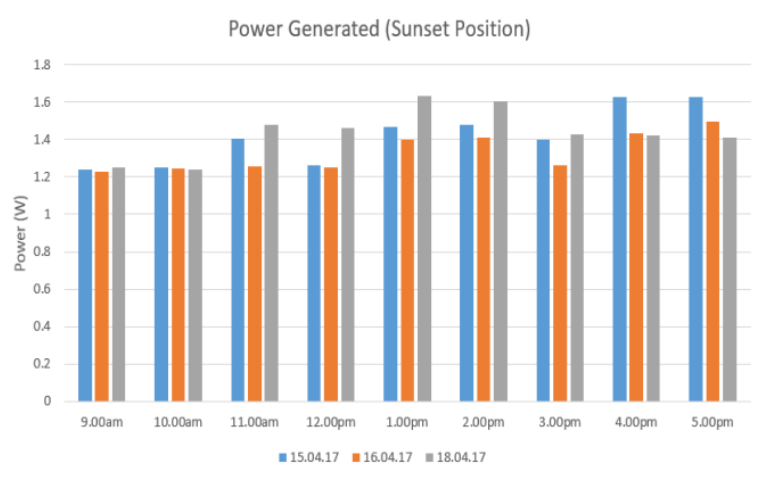

Fig. 14. Power from the sunset position.

Table 4 shown the maximum and minimum power generated by the solar according to its type of position. For the sunrise position, the maximum power generated is $2.4 \mathrm{~W}$, while the minimum power generated is $0.4 \mathrm{~W}$. For the upward position, the maximum power generated is $1.7 \mathrm{~W}$ and the minimum power generated is $0.38 \mathrm{~W}$. For the sunset position, the maximum power generated is $1.63 \mathrm{~W}$ and the minimum power generated is $1.21 \mathrm{~W}$.

\subsubsection{Prototype of Project}

Figure 15 shows the prototype of solat energy measurement using arduino uno. The best position of the solar panel energize was the sunrise position with the highest voltage value which is $14.75 \mathrm{~V}$ at time $11.00 \mathrm{am}$ have been recorded. At this time the light intensity was

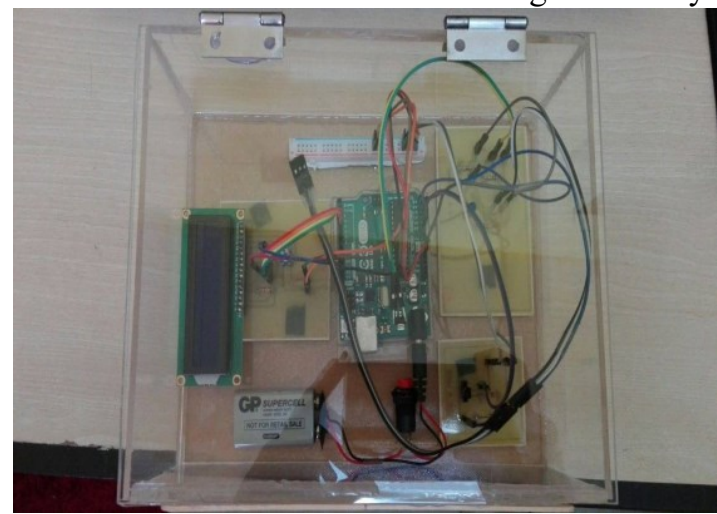

954 lux and the temperature was at $34.32{ }^{\circ} \mathrm{C}$.

Fig. 15. The Prototype of Solar Energy Measurement

Table 4. Maximum and minimum output power.

\begin{tabular}{|c|c|c|c|}
\hline Position & Sunrise & Upward & Sunset \\
\hline Maximum & $2.4 \mathrm{~W}$ at & $1.7 \mathrm{~W}$ at & $1.63 \mathrm{~W}$ at \\
(W) & $4.00 \mathrm{pm}$ & $12.00 \mathrm{pm}$ & $5.00 \mathrm{pm}$ \\
\hline Minimum & $0.4 \mathrm{~W}$ at & $0.38 \mathrm{~W}$ at & 1.21 at \\
(W) & $5.00 \mathrm{pm}$ & $5.00 \mathrm{pm}$ & $9.00 \mathrm{am}$ \\
\hline
\end{tabular}

\section{Conclusion}

In the conclusion, the project is achieve all of the objective are : to measure solar panel parameter such as the temperature, light intensity, voltage and current. Using the temperature sensor that sense the changes in surrounding temperature, for the light intensity parameter was by using the LDR sensor, for the voltage parameter was by using the voltage divider method in order to reduce the maximum value of the solar panel to the voltage value suitable for the Arduino of power supply and lastly the current parameter was by using the current sensor module. Next, to find the best position and time for the solar power effectively energize the electricity. The data from measurement part shows that the best position of the solar panel effectively energize was the sunrise position with the highest voltage value which is $14.75 \mathrm{~V}$ at time $11.00 \mathrm{am}$ have been recorded. At this time the light intensity was 954 lux and the temperature was at $34.32^{\circ} \mathrm{C}$. Lastly, to develop a portable device for measuring the solar energy can be achieve with developing the light in weight of the casing of the device and the neat arrangement of the electrical component inside the casing. 
The authors would like to acknowledge the Research Management Center (RMC), Universiti Tun Hussein Onn Malysia (UTHM), Batu Pahat, Johor, Malaysia for the financial support of this search. This research is partly by RMC under the U861 (Tier 1) Grant.

\section{References}

1. M.R. Al Rashidi, M.F. Al Hajri, K.M. ElNaggar, A.K. Al-Othman, "A new estimation approach for determining the $I-V$ characteristics of solar cells", Electrical Engineering Department, College of Technological Studies (PAAET), Shuwaikh, Kuwait, (2011).

2. V. Ryan, what is solar energy? (2016, September 20) Retrieved from http://www.technologystudent.com/energy1/sol ar1.htm

3. John Balfour, "Introduction to Photovoltaic", United States of America, (2013).

4. Arindam Bose, Sounak Sarkar, Sayan Das, "Helianthus-a Low Cost High Efficient Solar Tracking System Using AVR Microcontroller", International Journal of Scientific \& Engineering Research, Volume 3, Issue 10, October (2012).

5. Mohsen Taherbaneh, A. H. Rezaie, H. Ghafoorifard, K. Rahimi and M. B. Menhaj, "Maximizing Output Power of a Solar Panelvia Combination of Sun Tracking and Maximum Power Point Tracking by Fuzzy Controllers", Hindawi Publishing Corporation, International Journal of Photoenergy, Volume 2010, (2010).

6. Yi-Hua Liu, Jia-Wei Huang, " A fast and low cost analog maximum power point tracking method for a low power photovoltaic systems", Department of Electrical Engineering, National Taiwan University of Science and Technology, 13 September (2011).

7. R. Ramaprabha, M. Balaji, B. L. Mathur. “ Maximum power point tracking of partially shaded solar PV system using modified Fibonacci search method with fuzzy controller", Department of EEE, SSN Collage of Engineering Chenmai, India, 10 July (2012).

8. Mohammad H. Moradi, Ali Reza Reisi, " $A$ hybrid maximum power point tracking method for photovoltaic systems", Department of Electrical Engineering, Faculty of Engineering, $\mathrm{Bu}$ Ali Sina University, Hamedan, Iran, 14 September (2011).

9. Mybotic (2010) Solar cell 12 V 250mA (2016, November 20), retrieve from http://www.mybotic.com.my/webshaper/store/v iewProd.asp?pkProductItem=831

10. Chua Hock-Chuan (2015) Getting Started with Arduino (2016, October 30), retrieve from https://www.ntu.edu.sg/home/ehchua/program ming/arduino/Arduino.html

11. Electrical 4U.com (2011) Light Dependent Resistor / LDR and working Principle of LDR
(2016, November 2) retrieve from http://www.electrical4u.com/light-dependentresistor-ldr-working-principle-of-ldr/

12. Taxes Instrument (2016) LM35 precision centigrade temperature sensors (2016, November 4) retrieve from http://www.ti.com/lit/ds/symlink/lm35.pdf

13. SparkFun (2015) Voltage Divider (2016, November 6) retrieve from https://learn.sparkfun.com/tutorials/voltagedividers

14. Engineer Garage (2012) LCD ( 2016, November 7) retrieve from http://www.engineersgarage.com/electroniccomponents/16x2-lcd-module-datasheet

15. Wikipedia (2016) Proteus Design Suite ( 2016, November 21) retrieve from https://en.wikipedia.org/wiki/Proteus_Design_S uite

16. Arduino (2016) Overview of the Arduino, ( 2016, November 21) retrieve from https://www.arduino.cc/en/Main/ArduinoBoard Uno

17. Mohd Rashid B. Mohd Kamlon, "Solar Power Measurement System", Universiti Teknikal Melaka Malaysia, (2007).

18. Ganiyu R. A., Arulogun O. T. and Okediran O. O, (2014), Development of A MicrocontrollerBased Traffic Light System For Road Intersection Control, Journal of Scientific and Technology Research, vol. 3, p.1-4.

19. Vulnerable space blogspot (2016) Arduino Welcome to World, (2016, December 14) retrieve from http://vulnerablespace.blogspot.my/2016/01/ard uino-welcome-to-world-of.html.

20. Wikipedia (2016) Current sensor module 5A, (2016, December 22) retrieve from https://www.elecrow.com/wiki/index.php?title= ACS712_Current_Sensor-_5A.

21. Siti Amely Jumaat, Firdaus Mohammad, Shamsul Aizam Zulkifli, Development of Portable Case Solar Battery Charger, Electricial and Electronics Engineering 2016, 6(4) : 55-61, DOI : 1-.59923/j.eee.20160604.01 (2016).

22. Idris. I, Robian. M.S, Mahamad. A.K, Saon. S, 'Arduino based maximum power point tracking for photovoltaic system', APRN Journal of Engineering and Applied Sciences, Volume 11, Issues 14, (2016), pp 8805-8809.

23. Zulkifli. S.A, Hussin M.N, Saad A.S, 'MATLAB-Arduino as a low cost microcontroller for 3-phase inverter', 2014 IEEE Student Conference on Research and Development, SCOReD 2014. 